
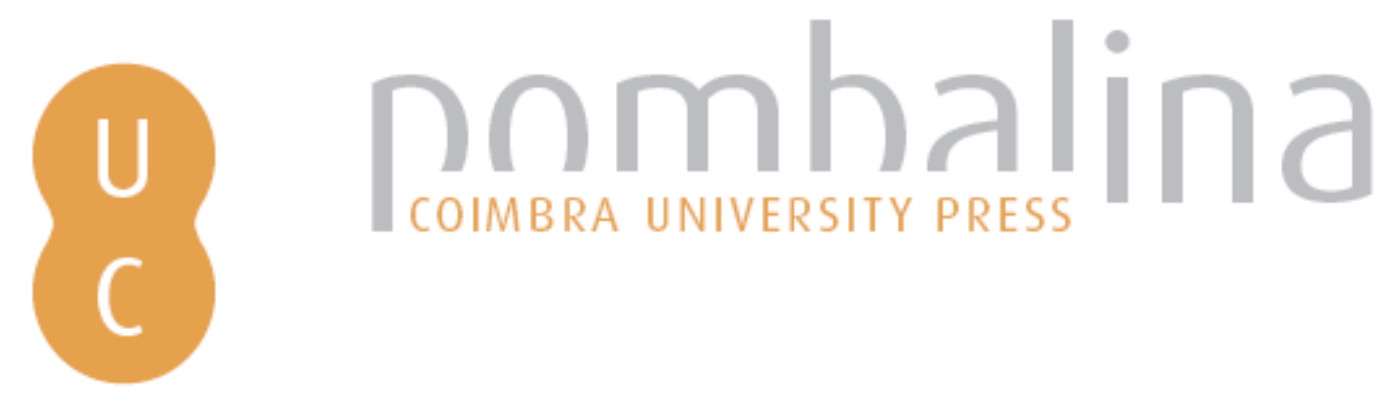

\title{
Zeus Kasios or the Interpretatio Graeca of Baal Saphon in Ptolemaic Egypt
}

Autor(es): $\quad$ Oliveira, Alexandra Diez de
Edições Afrontamento; CITCEM - Centro de Investigação
Publicado por: Transdisciplinar «Cultura, Espaço e Memória»; Centro de Estudos
Clássicos e Humanísticos; Alexandria University; Imprensa da Universidade de Coimbra

URL $\quad$ URI:http://hdl.handle.net/10316.2/36182

DOI: $\quad$ DOI:http://dx.doi.org/10.14195/978-989-26-0966-9_16

Accessed : $\quad$ 26-Apr-2023 16:33:59

A navegação consulta e descarregamento dos títulos inseridos nas Bibliotecas Digitais UC Digitalis, UC Pombalina e UC Impactum, pressupõem a aceitação plena e sem reservas dos Termos e Condições de Uso destas Bibliotecas Digitais, disponíveis em https://digitalis.uc.pt/pt-pt/termos.

Conforme exposto nos referidos Termos e Condições de Uso, o descarregamento de títulos de acesso restrito requer uma licença válida de autorização devendo o utilizador aceder ao(s) documento(s) a partir de um endereço de IP da instituição detentora da supramencionada licença.

Ao utilizador é apenas permitido o descarregamento para uso pessoal, pelo que o emprego do(s) título(s) descarregado(s) para outro fim, designadamente comercial, carece de autorização do respetivo autor ou editor da obra.

Na medida em que todas as obras da UC Digitalis se encontram protegidas pelo Código do Direito de Autor e Direitos Conexos e demais legislação aplicável, toda a cópia, parcial ou total, deste documento, nos casos em que é legalmente admitida, deverá conter ou fazer-se acompanhar por este aviso.

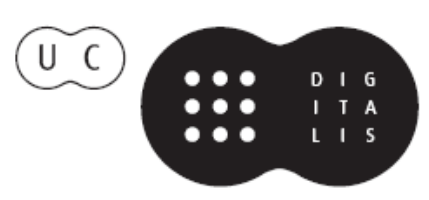




\title{
ZEUS KASIOS
}

\section{OR THE INTERPRETATIO GRAECA \\ OF BAAL SAPHON IN PTOLEMAIC EGYPT}

\author{
ALEXANDRA DIEZ DE OLIVEIRA
}

Centro de História (University of Lisbon).

\begin{abstract}
This essay's aim is mainly to understand and explain the characteristics of Zeus Kasios cult in Ptolemaic Egypt as an avatar or manifestation of the Semitic god Baal-Saphon already worshipped in Egypt in early periods. This Oriental form of the Greek god Zeus, worshipped in Mountain Kasios, Syria, was also found in the Egyptian Mount Kasios which points out to a cultural and religious diffusion movement, due to geographical proximity of both centers of cult and also due to the establishment of syropalestinian populations in Egypt since the times of the Hyksos invasion, which made easy the religious acculturation and syncretism between divinities.
\end{abstract}

\section{THE SOURCES}

The cult to Zeus Kasios in ancient Egypt is well known and widely referenced in a number of historical sources from the Classical to the Arabian Period. These sources are not consensual about the accurate location of the mount Kasios or Kasion, the place where there would have been one of the most important cult centers to this divinity. The epithet Kasios finds no parallels in native Greek cults and it is usually accepted that its basic etymological designation came from the Hurrian mount $\mathrm{Hazzi}^{1}$.However, a sanctuary dedicated to a god

\footnotetext{
${ }^{1}$ SALAC, 1922: 180.
} 
named Zeus Kasios, upon the Egyptian mount Kasios is quoted by the ancient Greek sources as the main cult center in the Ptolemaic Period, among other sites occasionally referred to.

The association that can be establish between both deities relies essentially on the information gathered from textual sources, most of them from the Greco-Roman Period, that associate the cult of Zeus Kasios to these two locations sharing a similar name but in distinct geographic places.

Archaeological dissemination of this cult is also attested in Syria, in Corcyra ${ }^{2}$ and Delos - and there is also an account of its diffusion to the Iberian Peninsula, especially to cape Palos and cape Saint Vicent ${ }^{3}$.

In Strabo's work several mentions are made to the cult of this form of the god Zeus in a location called Pelusium, in Egypt, dating back to the reign of Seleucus I, Nicator ${ }^{4}$ (306-280 B.C.), in a sanctuary nearby the Lake Sirbonis, thereby near a sandhill identified as Kasios. The temple would have been raised in a sandy promontory that wouldn't exceed 100 meters high, in close proximity to the Mediterranean Sea.

Strabo mentions that, while he was staying in Alexandria, a significant earthquake affected the region. Seemingly the earthquake changed drastically the topography of the area thus increasing the difficulty in identifying the geographical location of the so-called «mount». The author references that the sea raised so high in that region that flooded the surrounding area of the mount, becoming almost possible to cross all the way to Syria by boat ${ }^{5}$.

The area presents four toponyms involving the name «Kasion»; mount Kasion, Pompeius Magnus tomb, a sanctuary dedicated to Zeus Kasios and a small village named Kasios ${ }^{6}$. Both the tomb and the sanctuary were settled by the author on mount Kasion.

Flavius Josephus narrative describes how Vespasian's son, Titus Caesar, in the year 70 A.D., during his campaign into Jerusalem, while ${ }^{7}$ reorganizing his army, set his camp near a temple dedicated to Jupiter Kasios. This fact tells us that the temple would have been situated in a main terrestrial road, near the border of the Syro-Palestinian territory.

In his Natural History Pliny also mentions the mount Kasios ${ }^{8}$; he alludes to the Lake Sirbonis, as an insignificant swamp (ca. 1st century B.C.) placing the mount - initially far

\footnotetext{
${ }^{2}$ The city of Cassiopeia in Corfu island would have had its etymology in the word Kasios, due to the cult dedicated to Zeus Kasios. FENET, 2005: 39-49.

${ }^{3}$ PEREA YÉBENES, 2004: 95-112.

${ }^{4}$ Geography, I, 31; X, 5, 18; XVI, 12, 1-5; XVI, 8, 17-31; XVI, 26, 11-21; XVI, 28, 12-15; XVI, 32, 1-8; XVI, 33, 9-16; XVI, 34, 117; XVII, 11, 41-52.

${ }^{5}$ CLÉDAT, 1923: 65.

${ }^{6}$ Issues about the orthography that several Greek sources point out in the use of the Greek word «Kasion» or «Kasios» are not to be discussed in this work. The same to the Latin use of «Casion» or «Casios». Cf. VERRETH, 2006: 423-425 and 989-991.

7 The Jewish War, IV, 11, 5; In the Latin sources Jupiter was also identified with Zeus.

${ }^{8}$ Pliny's Natural History, 5, 12, 65.
} 
in the North - westwards of the lake', but considering the innumerous changes that local topography suffered throughout the ages, an inequivoque geographic identification once again becomes a very difficult task.

In the 5th century B.C., Herodotus mentions a mount Kasios as a border settlement between Egypt and Syria ${ }^{10}$ and locates it in the Mediterranean coastline. In its History ${ }^{11}$, in the account on the military campaign of King Cambyses against Egypt, Herodotus mentions the Pelusian region and the proximity of the Egyptian Kasios whose hillside touched the sea. He adds that is from Lake Sirbonis (where the monster Typhon would be hidden) that resides the entrance of Egypt ${ }^{12}$. This land was named by the Greeks as Kasiotide, upon the village that would be located at the foothill of the mount nearby the lake. There, would have been erected a sanctuary dedicated to Zeus Kasios ${ }^{13}$.

Around the 5th century A.D. sources refer to another cult place dedicated to the same god, in Egypt, in the northeast region of Sinai - at the present time called Tell Farama which is today's designation of Pelusium - in the proximity of mount Kasios, where it was found a temple dedicated by the navigators to the cult of this form of Zeus.

The geographic proximity from both Egyptian places and the toponymic resemblance creates number of doubts regarding the emplacement of the Egyptian temple of Zeus. Once again, the epithet Kasios given to the god Zeus that received cult at Pelusium, is due to the existence of a hill - located eastwards from Pelusium - mentioned in the sources as «mount Kasios» or «Kasion». Several authors identify the place southwest, approximately $60 \mathrm{~km}$ from Pelusium, thus located in the route for Syria.

The Alexandrian writer Aquila's Tacitus gives us account of the cult he performed in Pelusium, before the statue of this god which the author describes as having resemblances with Apollo due to his iconography (a representation of a young man holding a pomegranate) ${ }^{14}$.

The existence of a temple dedicated to Zeus Kasios in Syria - this far in a mountain which toponym is also Kasios - suggests that the development of this cult in Egyptian territory could have been originated in the Syrian mountain Kasios. Votive stocks of anchors were found nearby with dedication to this manifestation of Zeus.

In this viewpoint of the classical sources, references to the cult of Zeus Kasios, are not conclusive, upon the fact of being mentioned either the Syrian mountain Kasios or its Egyptian homonym. The proximity of both centers of cult and the acknowledgment of the same toponym are partially responsible for this situation.

\footnotetext{
${ }^{9}$ Op. Cit., 5, 14, 68; 6, 33, 167.

${ }^{10}$ History, 2, 6, 1; 2, 158, 4; 3, 5, 2-3.

${ }^{11}$ Idem, 3,5.

${ }^{12}$ CLÉDAT, 1923: 76.

${ }^{13}$ Idem, 80.

${ }^{14}$ Leucippe and Cleitophon, III, 6.
} 
Nevertheless, the existence of both temples of Zeus attests the diffusion of religious cult from Syria to the Egyptian territory thus following the usual pattern detected in the material culture: cults (attested by stock anchors inscribed with divine names) spread from a central temple to the territories under its influence, thus originating the erection of other temples, usually in the coastline, built upon hills, capes or promontories.

The diffusion of these cults was certainly facilitated by the displacement and establishment of Greek and Semitic populations throughout the 10th century B.C. in the coastline of the Eastern Delta, a movement that had an important impact in the area. Furthermore, contacts between Egypt and Syria-Palestine ended with Greek piracy that frequently ravaged the area, bringing prosperity and stability ${ }^{15}$, thus creating the conditions for the construction of new sacred buildings.

\section{BAAL SAPHON}

The introduction of Canaanite gods in Egypt dates back from the occupation of the Hyksos, along the Second Intermediate Period (ca. 1780-1560 B.C.). Knowing a widespread diffusion all over the Mediterranean basin, the Ugaritic god Baal was introduced in Egypt as well, where he was identified with other autochthonous divinities, such as Montu or Seth, thus integrating a dual identity composed of Ugaritic features of Baal and attributes borrowed from Egyptian gods.

Comparison between Ugaritic textual description of Baal and the Egyptian iconography allows identifying several places where the god received cult. Egyptian iconography shows evidence of exogenous features probably derived from the very definition of Baal as attested in Ugaritic literature, such as «Cycle of Baal».

Baal Saphon is an Ugaritc manifestation of Baal that deals with the control of the atmospheric phenomena such as storms, thunders and lightening. It's not in strict senses a marine divinity but a god that bears a protective and favoring nature for navigators and their maritime wanderings.

Baal Saphon's worship in Egypt goes back to the Second Intermediate Period, as attested by a seal-stamp from Tell el Da'ba, in the Eastern Delta ${ }^{16}$. The Egyptian god Seth would have assimilated some of the attributes of the Syrian god Baal, especially those concerning to atmospheric phenomena, like the storms, retaining a few of the typically Syrian features of Baal ${ }^{17}$.

\footnotetext{
${ }^{15}$ CLÉDAT, 1923: 157.

${ }^{16}$ It was found in Tell el-Da’ba a seal-stamp where this divinity was represented. Iconographically a Syrian smiting god, in a standing position, with a long bear and each foot on a mountain. In one hand he brandishes a spear in the other an axe. In is front, left side the image of a boat with two human figures rowing. This depiction is related to a divinity with climatic functionalities. Cf. PORADA, 1985: 485-488.
}

${ }^{17}$ PORADA, 1985:157. 
Evidence of worship in a number of locations testifies the ongoing cult performed to Seth/Baal-Saphon until the Ramesside Period. In Memphis, a Phoenician papyrus dated from the second half of the 6th century B.C., provides an interesting evidence on the diffusion of the this cult in Egypt. It consists on a private letter where a woman, probably living in Tahpanhes, salutes another one living in Memphis, in the name of Baal Saphon and other gods of Tahpanhes ${ }^{18}$.

Three references to mount Saphon can be found in a block of Aramaic texts in demotic writing, originated from Memphis, dating probably from the 5th century B.C., in close relation to the god Baal ${ }^{19}$.

Papyrus Sallier IV (v.s 1.6) - dating from the Ramesside Period - provides a list of divinities from Memphis mentioning Egyptian gods followed by a list of Canaanite divinities $^{20}$, where, among others, the name of Baal Saphon is cited.

During the 19th Dynasty Baal Saphon was worshipped under the form of the god Seth in Pi-Ramesse, the Egyptian capital in the Ramesside Period ${ }^{21}$. The earliest cult dedicated to this Syro-Palestinian deity was found in a temple in the city of Ugarit, located in mountain Saphon. Inside the temple innumerous deposits of votive block-anchors were found, material remnants that corroborate the marine protective character of this god ${ }^{22}$.

We must also bear in mind that in the Egyptian pantheon there was not a god that could correspond to the protective needs of sailors travelling in open sea. This god was worshipped in Peru-Nefer harbour, that according with Bietak's point of view would be located not in the surroundings of Memphis but closer to the Mediterranean, in Avaris ${ }^{23}$.

This fact might have favored the penetration of the cult of Baal Saphon in Egypt which would have filled a gap in the Egyptian pantheon. The worship of Baal Saphon thus was concerned with the protection of navigators in open sea, which differs from riverine sailing.

Under the Greek domination, Baal Saphon was related with Zeus Kasios an oriental manifestation of Zeus which worship spread all over the oriental Mediterranean, not only in Ugarit and Egypt but also into the islands of Corcyra and Delos.

In the Book of Exodus, (Ex. 14: 2, 9) along the route of the Exodus it is mentioned a place near Baal Saphon, by the sea, where Pi-hahiroth should be located.

This place becomes the focus of an endless discussion in order to trace the route of the Exodus. In Nu, 33: 7 it would be «between de Migdol and the sea» ${ }^{24}$.

\footnotetext{
${ }^{18}$ Cf. VERRETH, 2006: 427.

${ }^{19}$ VERRETH, 2006: 428.

${ }^{20}$ Divinities such as Baalat and Kadeshet. It can also be pointed up the reference to these divinities in the papyrus Hermitage 1116 A (vs. 42), where Baal is included, VERRETH, 2006: 167.

${ }^{21}$ BIETAK, 2011: 22-23.

${ }^{22}$ PEREA YÉBENES: 2004: 99.

${ }^{23}$ BIETAK, 2011: 26-29.

${ }^{24}$ CHOMSKY, 1993: 99-101.
} 
The association between the location where Baal Saphon would have had a temple and the biblical route of Exodus sets the chronology of Baal Saphon's cult, back to the New Kingdom, and somehow coherent with Late Greek and Roman sources, references of the sanctuary, that later would be associated to Zeus Kasios.

\section{ZEUS KASIOS}

The worship to Zeus Kasios emerged in Egypt in the Ptolemaic Period ${ }^{25}$ in the sequence of miscegenation of attributes from a native Greek god - Zeus - with an autochthonous one, originally from Ugarit, Baal Saphon. This last god was introduced in Egypt due to the geographic proximity and to the regular cultural, economic and warlike contacts developed since the Second Intermediate Period, until the Greco-Roman Period.

The migration of Asiatic and Greek populations into Egyptian territory, had consequences on the religious interaction within local communities, which becomes visible in the material evidence ${ }^{26}$ attesting a continuous acculturation. In this context Zeus Kasios emerges as an oriental manifestation of Zeus, merged with the local cult of Baal Saphon. Both gods shared several specificities, mainly due to the fact they are both divinities related to mythical mountains ${ }^{27}$ and both had power over atmospheric phenomena.

According to textual sources, the epithet Kasios seems to be related to the primordial place of worship of this avatar of Zeus in Ugarit, Syria. During the Greek occupation, the Ugaritic mountain Saphon was renamed as Kasios. Nearby in Egypt, close to the important trade route know as "Ways of Horus», supposedly named after the original mountain in Ugarit, layed its homonym, the Egyptian mount Kasios.

Zeus Kasios's avatar is often depicted under the form of a young man's image showing clear affinities with another Greek god, the young Apollo and to Harpocrates, the Hellenized designation of the Egyptian god Horus ${ }^{28}$.

A coin, dated from 109 A.D. (Emperor Trajan's reign) referring to the province (or the Greek designation nomo) of Pelusium, presents an image of Harpocrates wearing the Egyptian hemhemet-crown ${ }^{29}$, holding a scepter in the left hand and a grenade in the right hand.

The classical writer Aquila Tacitus in his work Leucippe and Cleitophon mentions the existence of a statue dedicated to Zeus Kasios in Pelusium; it describes this statue as the image of a young man similar to Apollo's, holding a grenade in his stretched hand ${ }^{30}$. This

\footnotetext{
${ }^{25}$ Ca. 332 B.C.E.

${ }^{26}$ These evidences can be found in onomastic, toponymia, and in private and royal cults.

${ }^{27}$ Zeus from the mount Olympus, and Baal Saphon from the mount Saphon.

${ }^{28}$ BONNER, 1946: p. 52.

${ }^{29}$ According to COOK, 2010: 987, the Egyptian hemhemet-crown was one of the iconographical marks of Zeus Kasios, due to the fact that appears associated to the divinity name, even when there is no visual representation of the god.

${ }^{30}$ Leucippe and Cleitophon, III, 6.1.
} 
description is also coincidental with the Apollonian representation that figures in Trajan's coin, also from this area. In Leucippe and Cleitophon it is attributed an oracular ability to the divinity. The characters should make a plea and run a complete turn around the temple, fulfilling a ritual in exchange for an oracular prediction, about the shipwrecked person's destiny. This feature of Zeus Kasios agrees with the apollonian appearance and with Apollo's oracular ability. Moreover, Leucippe and Cleitophon provides a brief description of the image and attributes of the god, confirming the visual attributes found in the Trajan's $\operatorname{coin}^{31}$.

Archaeological excavations carried out by Jean Clédat, in the coastal region of Pelusium brought to daylight the remains of an ancient temple from Adrian's reign (ca.122 A.D.) that according to the inscriptions was dedicated to Zeus Kasios ${ }^{32}$. Littman also references a very damaged Nabatean inscription found in El-Mahemdiya by the French Egyptologist Jean Clédat, were the name Zeus Kasios was inscribed. The inscription would have been found in an alabaster altar niche of the sanctuary ${ }^{33}$.

The earliest cult known to Zeus Kasios would have its origins in a sanctuary located in a region $40 \mathrm{~km}$ from Ugarit, near Antioch, at the mouth of the Orontes River, corresponding to the mountain Saphon. Kasios or Kasion was the Greek designation.

\section{CONCLUSIONS}

All the region of the Delta was deeply Hellenized since the 3rd century B.C. onwards and for centuries it was a crossroad for Semitic and Near Eastern contacts thus facilitating the introduction and diffusion of Asiatic divinities that assume similar functions within the Egyptian pantheon.

It seems consensual among scholars the opinion that Zeus Kasios was an oriental interpretation graeca of the Greek native god Zeus, synchretized with the Canaanite god Baal Saphon, both in Antioch and Egypt during the Ptolemaic Period.

This manifestation of Zeus found in Egypt, mainly in locations where Baal Saphon was worshipped, most of them located in emplacements related to sea harbours or in the proximity of the Mediterranean Sea. This fact may be a lead to determine that Zeus Kasios in spite of not being a sea god was indeed a protective deity of the seafarers of the Mediterranean.

\footnotetext{
${ }^{31}$ PEREA YÉBENES, 2004: 104.

${ }^{32}$ It is a question of debate whether this temple rehabilitated previous existent structures of an earlier temple dedicated to the same divinity or if it was erected from scratch. Cf. CLÉDAT, 1913: 79-85.

${ }^{33}$ LITTMANN, 1954: 230-231.
} 
Archaeological evidences show that Zeus Kasios was not only worshipped in the original Mountain Kasios, in Syria and Egypt. His cult also reached Delos, Corcyra and even the far Cape of Palos, in the Iberian Peninsula.

Zeus Kasios while absorbing some of the divine attributes of Baal Saphon, also captured some other features from the Greek god Apollo which was worshipped in this period in Pelusium as a Greek manifestation of the Egyptian god Horus. The Egyptian cult of Zeus Kasios thus presents an Hellenistic form of Horus that gather characteristics from Syrian, Egyptian and Greek divinities. This cult reflects the fusion of several cultural traditions present in the Delta.

Furthermore, the fusion of qualities taken from divinities with several origins and provenances aiming to fulfill a certain gap within the religious experience of the populations is a phenomenon typical of the multicultural background of the Hellenistic civilization.

The affinities between both gods as mountain divinities, Zeus from the Olympus and Baal from Mount Saphon, smooth the progress of blending the qualities of Baal Saphon into those of the Greek Zeus, creating a new Oriental metaphor, Zeus from the Mount Kasios, in Syria.

The nature of this cult and the proximity to other known centers of worship let us assume the possibility of diffusion of these practices especially towards Egypt where Baal Saphon was already worshipped since earlier periods. The establishment of another location of the cult with the same name Kasios, also dedicated to Zeus Kasios but in Egyptian territory, with earlier references of a sanctuary dedicated to Baal Saphon could document the need to reproduce the Syrian Mountain Kasios in Egyptian soil.

This cult extended itself through the Mediterranean basin until the Roman era under the name of Jupiter Cassius. 